\title{
Catholic Action in Davenport: St. Ambrose College and the League for Social Justice
}

\section{GEORGE WILLIAM MCDANIEL}

IN NOVEMBER 1950 Mike Lawrence invited a group of friends to his apartment to discuss current issues in the world, in Davenport, and in the Roman Catholic Church. The members of the group came from varied backgrounds. Some were students or graduates of St. Ambrose College or Marycrest College. Some were veterans of World War II. Others had some experience with civil rights issues. A few, like Lawrence, had backgrounds in labor unions. But in one way or another they all had come into contact with priests and lay faculty at St. Ambrose College and their ideas about Catholic social teaching. The group that gathered in response to Lawrence's invitation became the nucleus of the League for Social Justice, one of many specialized Catholic Action groups that were part of life in the Roman Catholic Church during what historian Debra Campbell has called the "heyday" of Catholic Action. ${ }^{1}$

This article first took form as the Baecke Chair of Humanities Lecture that I delivered on November 10, 1993, at St. Ambrose University. I am grateful to St. Ambrose and to Rae Baecke and the late Albert Baecke, who endowed the Baecke Chair, for their support for this project. Another version was read at the Iowa Heritage EXPO, June 11, 1994. Many members of the League for Social Justice shared their memories of the League. I am especially grateful to Mike and Phyllis Lawrence, Vaile and Mary Scott, Charles and Ann Toney, Jerome Cahill, William Nagle, Frank Klauda, and Joe and Mary Jean Blough. Perry Ramirez was very helpful with information about Cook's Point.

1. Debra Campbell, "The Heyday of Catholic Action and the Lay Apostolate, 1929-1959," in Transforming Parish Ministry: The Changing Roles of Catholic Clergy, Laity, and Women Religious, ed. Jay P. Dolan (New York, 1990).

THE ANNALS OF IOWA 55 (Summer 1996). CThe State Historical Society of Iowa, 1996. 
During its two-year existence, the League for Social Justice involved itself in several specific causes. It advocated the continuation of rent controls to protect low-income renters from postwar inflation. Its members spread throughout the community to identify and call attention to lingering racism in Davenport. And they sought to bring responsible members of the community together to find suitable housing for Mexican-American residents displaced from a squatter settlement in the city. The League's efforts focused largely on education and mediation. While not always successful in altering the course of public policy, the League did force the community to face some of the injustices in its midst. And League members were forced to confront their own attitudes about race, discrimination, social justice, and the appropriate Christian response.

LAWRENCE AND HIS FRIENDS were not alone in their interest in social justice issues. Since the 1930s groups of Catholics had taken an interest in the connection between the gospel message of concern for the poor and the needy and injustice in society. The institutional church encouraged this interest under the general concept of "Catholic Action," which promoted the cooperation of the laity in the work of the hierarchy. As part of Catholic Action, groups formed to address specific issues in society and engage in specialized Catholic Action. Often formed outside formal parish structures, these groups emphasized lay activity. ${ }^{2}$ Usually a priest was involved and acted as the chaplain of the group. But in some instances, priests were merely "clerical midwives," who "assisted at the birth" of a group but had little regular contact with it. ${ }^{3}$

Such groups were animated by a series of papal encyclicals that spoke about the church and society. The first, Leo XIII's Rerum Novarum (1891), gave papal approval to labor organiza-

2. Jay P. Dolan, The American Catholic Experience: A History from Colonial Times to the Present (Garden City, NY, 1985), 396. For background on specialized Catholic Action, see Dennis Michael Robb, "Specialized Catholic Action in the United States, 1936-1949: Ideology, Leadership, and Organization" (Ph.D. diss., University of Minnesota, 1972).

3. Campbell, "Heyday of Catholic Action," 222. 
tions and urged the church to work for social justice. Forty years later, in Quadragesimo Anno (1931), Pius XI said that in a world facing totalitarianism Catholics have a special responsibility to work for social justice. Pius XII argued in Mystici Corporis (1943) that each member of the body of Christ (the church) was graced with particular gifts that should be used for the improvement of the whole body. Finally, in Mediator Dei (1947), Pius XII connected the way people worshiped with the way they lived their lives in society. Taken together, these encyclicals exhorted lay Catholics to work together with the clergy and the hierarchy to promote social justice.

In the United States, Father John A. Ryan adapted the principles of the papal encyclicals to the American situation. In his works on distributive justice and a living wage, Ryan acclimated the church's traditional theology to the norms of twentieth-century industrial society; at the same time he galvanized "Catholic pressure on the modern state to deal effectively with social problems." Ryan's views reached a wide audience in 1919 when he wrote the American bishops' Program of Social Reconstruction. Moreover, as a teacher at the Catholic University of America, Ryan was a major influence on American seminarians and clergy who studied there in the $1920 \mathrm{~s}$ and $1930 \mathrm{~s}^{4}$

If the papal encyclicals and John Ryan's work provided the intellectual underpinnings for specialized Catholic Action, Father Joseph Cardijn provided a methodology. Born in Belgium and ordained in 1906, Cardijn taught college for five years and studied working-class conditions in Europe. Concerned that many young workers had abandoned their faith, he urged them to look at life in their workplace and, by replacing human vision with the vision of God, to transform their world. This developed into his simple methodology of "see, judge, act," which became the operating principle of his groups. ${ }^{5}$ Cardijn soon organized the Young Christian Workers (in French, the Jeunesse Ouvriere

4. Francis L. Broderick, Right Reverend New Dealer: John A. Ryan (New York, 1963), 278. Ryan's major works are A Living Wage: Its Ethical and Economic Aspects (New York, 1906); and Distributive Justice: The Right and Wrong of Our Present Distribution of Wealth (New York, 1916).

5. Joseph Cardijn, Laymen Into Action (London, 1964) 50, 148, 149. 
Chretienne, abbreviated as JOC, which gave the groups the popular name of Jocists). Later he formed a similar group for students called the Young Christian Students, or YCS. ${ }^{6}$

By the 1940s, these ideas were a part of the fabric of life at St. Ambrose College. Founded in 1882 by the first bishop of Davenport, John McMullen, St. Ambrose was a diocesan college established to serve the Diocese of Davenport. The bishop of Danvenport continues to serve as the chairman of the board of directors, and priests of the diocese serve on the faculty.

McMullen had come from Chicago, where, in addition to his other duties, he had been president of St. Mary of the Lake University. His biographer said McMullen's "great ambition" was to found his own college. McMullen believed that Catholics should receive an education that would integrate Catholic principles into all facets of their lives. St. Ambrose's first president, the Reverend A. J. Schulte, and his successors carried out McMullen's ideas of Catholic education. Speaking in 1901, Schulte said that "religion does not merely run parallel to the course of secular studies, but like a vitalizing sap, should enter into and pervade every fiber of them." ${ }^{17}$

The first faculty of the college consisted of Schulte, who taught religion and the classics and worked with students studying for the priesthood, and Mr. Joseph Halligan, who taught commercial courses. Although there would always be a few lay professors, until World War II the faculty consisted almost entirely of priests of the diocese.

The first students were from Davenport, but within a short time students came to St. Ambrose from throughout the diocese, and later the Midwest. At the beginning of World War II, 514 students were enrolled at St. Ambrose. But in the postwar years that number tripled, largely as the result of veterans taking advantage of the G.I. Bill. Many future League members came from this group, and their wartime experiences brought

6. Mary Irene Zotti, A Time of Awakening: The Young Christian Worker Story in the United States, 1938-1970 (Chicago, 1991).

7. Anthony Gorham Farrell, Bees and Bur Oaks: 100 Years of St. Ambrose College (Davenport, 1982), 20; James J. McGovern, The Life and Writings of the Right Reverend John McMullen, D.D., First Bishop of Davenport, Iowa (Chicago, 1888), 256. 
an added dimension to their discussions of a variety of reform issues, both within the church and in the larger community. ${ }^{8}$

THE IDEALS OF CATHOLIC ACTION continued the tradition established at St. Ambrose by McMullen and Schulte. The faculty of the college played a key role in transmitting those ideals. For example, Father Cletus Madsen, professor of music, was in the founding group of the national Liturgical Conference and was engaged in liturgical reforms that would come to fruition during the Second Vatican Council. Father Edward Catich, professor of art, asked people to view liturgical art as representative of their own time, speaking to them in a visual vocabulary that would be familiar to them. Together their work suggested a link between the liturgy and social justice. ${ }^{9}$ Msgr. Ulrich Hauber, professor of biology, worked to reconcile modern scientific ideas with traditional theology and scripture. In addition, along with Dr. Paul Sacco, Hauber was involved with rural life issues.

The issues that received the most publicity, however, were those related to race and labor. Here the guiding forces were the O'Connor brothers, Father Ed and Father Bill, plus Father Urban "Penny" Ruhl and Father Charles Griffith. These remarkable priests used their classes in sociology, philosophy, English, and history to teach about the social encyclicals and the issues of labor and race. Moreover, in good Jocist fashion they urged their students to get involved, to study a situation, and take action. For example, Father Ed O'Connor sent his classes into the community with a questionnaire to survey attitudes about race. Although about 2,500 African Americans lived in Davenport in 1950 (out of a total population of nearly 75,000), one student said she had lived in Davenport all her life but had never known a "single Negro." Unaware that there was so much "infringement" on the rights of blacks, she said this was her own "personal awakening to the situation."10

8. Bulletin of St. Ambrose College, 1942-1943 (Davenport, 1942), 212; Bulletin of St. Ambrose College, 1949-1950 (Davenport, 1949), 114.

9. Bill Nagle to author, 7 October 1993.

10. Joe and Mary Jean Blough, interview with author, Davenport, 21 July 1993. 
But the most visible of all the St. Ambrose faculty was Father Bill O'Connor. Father Bill had taken a Ph.D. in sociology at the Catholic University of America, where he had studied with Father John A. Ryan. He used his classes at St. Ambrose as a forum for the church's social teachings. As Mike Lawrence remembered, he was "ringing our ears for Rerum Novarum."11 Like his brother, Father Bill also created opportunities for his students to apply what they learned in class. In 1948, for example, he formed the Inter-Racial Club and had the members take a Quad-City Personal Poll to learn the economic status of African Americans in the Quad Cities. The poll sought information about living conditions, education levels, job status, and salary. The results of the poll indicated that there was a "high level of discrimination" in Davenport, which was "strictly, if not officially enforced" as African Americans were barred from restaurants, hotels, and barber shops. Most African Americans were unable to buy a home except in a few specified areas of town. Most had unskilled jobs that did not allow them to provide more than the bare necessities for their families. ${ }^{12}$

The O'Connor brothers also brought a variety of speakers to campus. In June 1941, for example, they organized a Social Action Conference to commemorate the fiftieth anniversary of Rerum Novarum. Speakers included Msgr. John A. Ryan; Dorothy Day, cofounder of the Catholic Worker movement; Msgr. Reynold Hillenbrand, rector of St. Mary of the Lake Seminary and a social activist in Chicago; John L. Yancy, a union activist and civil rights advocate; Meyer Kestnbaum, president of Hart,

11. Mike Lawrence, interview with author, Davenport, 22 July 1993.

12. Ambrosian News, 12 March 1948. Sample survey form and some poll results in Rev. William T. O'Connor Papers, Department of History, St. Ambrose University. The poll attracted statewide attention. Ambrosian News, 30 April 1948. The group took a similar poll of students at St. Ambrose which indicated that the students generally thought that Negroes should have opportunities for jobs and in public accommodations. Seventy-two percent said that they would not object to a Negro living on their block, and 81 percent said that they would not object to a Negro's application for membership in their church. Sixty percent said they would not object to working under the supervision of a Negro, but 51 percent said they did not favor a law forbidding an employer to discriminate based on race or creed. Ambrosian News, 28 May 1948; O'Connor Papers. 
Schaffner, and Marx; and Msgr. Luigi Ligutti, a St. Ambrose graduate and at that time Executive Secretary of the National Catholic Rural Life Conference. The conference organizers hoped it would create a "better understanding of the great purposes of human society and a better appreciation of the social values of human life."13

In the years following the war many speakers came to Davenport under the auspices of Te Deum, a speaker's bureau operating in the Middle West. Topics included labor issues, the Soviet Union, international politics, and scientific subjects. Mary Jean Blough, later a member of the League for Social Justice, remembered that these talks were quite popular and helped raise League members' consciousness of issues of social justice. ${ }^{14}$

Various student organizations played an important role in Catholic Action activities on campus. The Legion of Mary, which emphasized spiritual advancement, expected members to perform at least two hours of apostolic work each week. The moderator, Father Bernard Kamerick, believed that Catholic Action was an integral part of the educational process. Speaking in 1952, he said that "spirituality is something you can't absorb in the classroom: you've got to learn it the hard way: by doing." ${ }^{\prime 15}$

Eventually most of the social action activities at St. Ambrose, including a local chapter of Father Cardijn's Young Christian Students (YCS), fell under the aegis of the National Federation of Catholic College Students (NFCCS). Founded in 1937, its

13. Rev. Charles F. Griffith, Catholic Messenger, 12, 19, 26 June 1941. At about the same time Davenport Bishop Henry P. Rohlman sent a combined copy of Rerum Novarum and Quadragesimo Anno to the "Reverend Fathers, Venerable Sisters, and Faithful Members of the Laity" of the diocese. Rohlman wrote that people must be familiar with the principles of the encyclicals and "bring others to know and appreciate them" so that when the war was over the principles of these documents could "form the basis" for the "reconstruction" of postwar society. Most Rev. Henry P. Rohlman to Dioecese of Davenport, n.d., in author's possession.

14. Joe and Mary Jean Blough, interview. Charles Costello, who taught speech and drama at St. Ambrose, was the local chairman of Te Deum.

15. New Catholic Encyclopedia, s.v. "Legion of Mary"; Catholic Messenger, 24 January 1952. 
purpose was to stimulate thought and action on current issues and to encourage personal commitment by the students to the work of the church. ${ }^{16}$ One of the earliest NFCCS workshops at St. Ambrose was held in November 1948. In his introductory remarks to the meeting, Davenport Bishop Ralph L. Hayes urged the students to "pool ideas" and "promote Catholic action." Father Joseph Schneider, the national promoter of Catholic Action for the NFCCS, was the principal speaker for the conference. Schneider said that organizations such as the NFCCS could be "instrumental in re-christianizing the youth of the world to aid in preventing further growth of secularism, materialism, and godlessness." The next year St. Ambrose hosted a regional NFCCS leadership conference that included panel discussions on Catholic action, Mariology, student government, international student relations, and press and publicity issues. ${ }^{17}$

The largest Catholic Action activity in those years was a fourday Conference on Social Responsibility held in March 1949. Conference attendees included clergy, religious, and lay people from all over the Midwest. St. Ambrose officials canceled classes to allow students to participate in all four days of the conference. Bishop Hayes delivered the keynote address. "These are not times for colorless neutrality," he told the participants. "The duty of the Christian is to share generously and courageously in the effort to solve these problems of social justice." Speakers came from national organizations such as the National Catholic Welfare Conference, the National Catholic Family Life and Rural Life Conference, the Catholic Conference on Industrial Problems, and the Catholic Association for International Peace. One session for the clergy concerned ministry to Spanish-speaking immigrants. The conference was a great success and illustrated well what the Ambrosian News meant when it said that "there was never in the past so great an interest on the campus in social problems" as now. ${ }^{18}$

16. New Catholic Encyclopedia, s.v. "National Federation of Catholic College Students."

17. Ambrosian News, 4 November 1948, 7 October 1949.

18. Democrat and Leader, 20, 21 March 1949; Ambrosian News, 11, 18, 25 March 1949. 
Apparently, however, not all St. Ambrose students thought that these activities were worthwhile. One student who signed himself as "Agitated Ambrosian," wrote in the Ambrosian News that the merits of the NFCCS did not equal its demerits. He said its delegates attended conventions and learned nothing. "As far as myself and a lot of other boys around campus can see," he continued, "nothing is ever derived from these get-togethers except some vocal experience for a small minority of 'Ambrosians' and some more money for the restaurants, hotels and public transportation companies." St. Ambrose student Tony Kuchan, vice-president of the Iowa region of the NFCCS, defended the organization. He claimed that the spiritual benefits of the NFCCS were "immeasurable." Moreover, he said, it provided an opportunity for the St. Ambrose student to get into Catholic Action. Without it, Kuchan concluded, St. Ambrose would be "stagnant."19

Life was hardly stagnant at St. Ambrose. In addition to conferences, student activity at St. Ambrose took a variety of other forms. For a number of years the students raised money for European relief. They held a forum on recent laws passed by Congress and the state legislature. When they sponsored a short story contest on the theme of minority groups, they suggested that contestants read the papal encyclicals and recent works by Jacques Maritain, John LaFarge, Gunnar Myrdal, and the President's Committee on Civil Rights. In 1948 student groups on campus sponsored a Catholic Action School for high school students, where college students presented talks on various aspects of Catholic Action to illustrate the opportunities for high school students to form groups in their schools. ${ }^{20}$

In addition to the many organized group activities, informal groups also formed. Bill Nagle, a future League member, recalled belonging to a group that included, among others, future League members Manning Keigher and Vaile Scott. They read and discussed the social encyclicals and the encyclical on the liturgy. League members also recall informal discussions in

\section{Ambrosian News, 19 May 1950.}

20. Ambrosian News, 14 October 1949, 24 February 1950, 13 February 1948, 15 December 1950, 14, 21 May 1948; The Crest, 19 May 1948. 
the student union and late-night discussions wherever students gathered. In fact, the message and the activities were difficult to avoid, and they had a great impact on the students. Looking back on those years, Mary Jean Blough said, "I don't think we realized . . . at the time that there was something different at St. Ambrose." Her brother, Bill Nagle, recalled that there was a "ferment" at the college that made it "something special." That ferment formed his social consciousness and instilled an activism that remains today. Mike Lawrence admitted that although he had a background in labor unions, his knowledge of social problems was "vague" until he was exposed to the social teachings of the church and the encyclicals. And Marvin Mottet remembered vividly the effect of the social justice message at St. Ambrose. "It hit me like a ton of bricks," he said. "Everywhere you turned you got it from the O'Connors, you got it from Grif, you got it from Ruhl ... [and you] wanted . . . to go out of there and knock down walls." ${ }^{21}$

BECAUSE OF THEIR ASSOCIATION with St. Ambrose College or the priests and lay people who taught there, the group of people who gathered in Mike Lawrence's apartment in November 1950 had something in common despite coming from a variety of backgrounds: they had been exposed to the social teachings of the Catholic church, and they had a model for Catholic activism.

Moreover, Lawrence had made trips to Chicago to observe the work of two specialized Catholic Action groups. The first was the Catholic Labor Alliance. Organized in 1943 by Ed Marciniak, Msgr. Reynold Hillenbrand, and others, the Alliance promoted trade unionism and labor schools, fought racial discrimination in housing, and sponsored retreats for its members. The members believed they should organize "not to serve private, selfish interests but to serve the common good." The other influence was Friendship House. Founded in Toronto in 1938

21. Bill Nagle to author, 7 October 1993; Joe and Mary Jean Blough, interview; Mary Jean Blough to author, 27 July 1993; "Focus on William J. Nagle," Ambrose Scene (Winter/Spring 1985); Catholic Messenger, 3 May 1951; Father Marvin Mottet, interview with author, Davenport, 23 July 1993. 
by Baroness Catherine de Hueck, a Friendship House opened in Chicago in 1942. Friendship House gave direct aid to the poor, sponsored educational workshops, and worked against racial discrimination by advocating social and political change. Seeing such groups in action enabled Lawrence to "grasp the real need for positive action." He hoped to replicate their work in Davenport. ${ }^{22}$

By April 1951 the Davenport group's discussions, the various models they had experienced in Chicago, and their college experience led them to conclude that they ought to "organize to do something realistic about promoting social justice." They wrote a constitution and organized as the Catholic League for Social Action. According to its constitution, the League was a "Catholic lay group actively working toward the reconstruction of the social order." Among the stated purposes of the League were to promote the principles of recent papal encyclicals on labor and the social order; to foster trade unionism as well as cooperation between labor and management; and to "work toward the complete integration of the Negro, Mexican and other minority groups into American society." Lawrence hoped that the group could do "realistic, positive, constructive work for social justice." ${ }^{\prime 23}$

During those first months Father Bill O'Connor, Father Bernard Kamerick, or Father Cornelius Bresnahan, a Viatorian priest, would occasionally meet with them. Lawrence said they wanted a chaplain to "keep us in line doctrinally and to guide us in the spiritual formation on which all social action depends." Yet they also wanted the organization to be a lay group. They did not want to constantly ask, "what does Father think?" or

22. Raymond John Maly, "The Catholic Labor Alliance: A Laboratory Test of Catholic Social Action" (M.A. thesis, University of Notre Dame, 1950), 15; "Salute to the Catholic Labor Alliance," Today, December 1953, 7; Bob Spenser, "Catholic Labor Alliance," The Catholic Mind, February 1951, 119-24; Catholic Messenger, 3 May 1951; Dolan, American Catholic Experience, 412-14. For the "Chicago connection" in general, see Steven M. Avella, This Confident Church: Catholic Leadership and Life in Chicago, 1940-1965 (Notre Dame, IN, 1992); for the Catholic Labor Alliance, see especially 180-82.

23. Catholic Messenger, 3 May 1951; Constitution of the Catholic League for Social Action, Archives, Diocese of Davenport. 
to have to check with "Father" before every action. Nevertheless, it is clear that Father Bill O'Connor was the impetus for forming the League, and he was, in Mike Lawrence's words, its "intellectual spark plug." ${ }^{24}$

That same month three members of the group-Mike Lawrence, John E. Nagle, and Mary Elizabeth Feeney - along with another Viatorian priest, Father John T. Ryan, met with Father Maurice Dingman, the vice-chancellor of the Diocese of Davenport, to present their constitution. They also gave Dingman a list of forty-two members that included white and black men and women, Catholics as well as Protestants. Dingman questioned calling the group a "Catholic" League since not all members were Catholic. They responded that Catholic social doctrine provided the League's organizing principles. Dingman then sent the information to Bishop Ralph L. Hayes for his approval. ${ }^{25}$

The bishop suggested that the group drop Catholic and action from its name and proposed instead the League for Social Justice. $\mathrm{He}$ also suggested that the constitution state general principles rather than advocate specific goals. For example, where the constitution said the League would "work toward the complete integration ... of American society," the bishop suggested that they say their purpose was "to promote inter-racial justice particularly regarding minority groups." $\mathrm{He}$ also suggested that they change "to promote trade unionism" to say "study the rights and obligations of employers and employees." Finally,

24. Catholic Messenger, 3 May 1951; Mike Lawrence, interview; Charles Toney, interview with author, Coal Valley, IL, 16 July 1993. Father Bresnahan, chaplain at Marycrest College from 1949 to 1955, was a member of the Clerics of St. Viator. Beginning in the late 1930s, students studying to become members of the order did their college work at St. Abrose. They lived in a house of studies near the campus, and a number of Viatorian priests taught at the college.

25. Memorandum, Dingman to Bishop Ralph L. Hayes, 12 April 1951, Archives, Diocese of Davenport; Abby Feeney Priester, interview with author, Davenport, 2 September 1993. In addition to the original list I have been able to locate two other membership lists. The second list dates from fall 1951 and has thirty-nine names. Phyllis Miller Lawrence Papers, in author's possession. The third list dates from 1952 and has forty-two names. Barbara Lee Klauda Papers, in author's possession. The membership was very fluid as people moved in and out of town. Moreover, a number of St. Ambrose and Marycrest students became members for a time. Only twenty names appear on all three lists. 
he agreed that priests and ministers should not be members but could be invited to the meetings "as consultors and advisors." 26

Part of the bishop's concern about the tone of the proposed constitution may have been that in its original form the League advocated too much social activism. In the years following the war there were hopes for the continuation of social reforms that had begun during the New Deal and as a consequence of wartime needs. By the early 1950s, however, hopes for such changes had been swept away as a prosperous United States espoused the ideals of conformity built on "harmonious relations among business, government, and labor." ${ }^{27}$

Moreover, Cold War fears had given rise to a red scare hysteria personified by Wisconsin Senator Joseph McCarthy. Any organization that was suspected of trying to change the basic fabric of American society became suspect. Thus, within a few months an FBI agent called on Mike Lawrence to ask about the League, its philosophy, and purposes. One consequence of the FBI's interest was that the League had to change its meeting place. It had been meeting at the Davenport Public Library, but when library officials learned of the FBI's inquiries, they told the League it could no longer meet there. ${ }^{28}$

In the meantime, the members met and accepted all of the bishop's suggestions. With the constitution approved, the League elected officers. Mike Lawrence became president; Charles Toney, vice-president; Mary Elizabeth Feeney, secretary; and Jim Lawrence, treasurer. Ed McGovern, Phyllis Miller, and Barbara Lee were named to join the officers on the executive board. The group also began publication of a monthly newsletter, the Mediator. ${ }^{29}$

26. Bishop Ralph L. Hayes to Very Rev. John T. Ryan, C.S.V., 19 April 1951, Archives, Diocese of Davenport.

27. Norman L. Rosenberg and Emily S. Rosenberg, In Our Times: America Since World War II, 5th ed. (Englewood Cliffs, NJ, 1995), 66.

28. Mike Lawrence, interview; Catholic Messenger, 3 May 1951; Joe and Mary Jean Blough, interview; Abby Feeney Priester, interview. A request for FBI files filed under the Freedom of Information Act turned up nothing for the League for Social Justice, Mike Lawrence, or Bill O'Connor.

29. Very Rev. John T. Ryan, C.S.V., to Hayes, 26 April 1951, Archives, Diocese of Davenport; Catholic Messenger, 3 May 1951. When Mike Lawrence moved to Indiana in late 1951 to take a new job, Vaile Scott became the new 
The League met twice a month and charged its members modest dues. Lawrence said they would not beg for funds from outside; if the members were not interested enough to support the League, it should not continue. In addition to the regular meetings, some members continued to meet to study the encyclicals, especially the two encyclicals of Pius XII on the Mystical Body and the liturgy. They had become convinced that understanding and living the liturgy formed an "indispensable basis for Christian social action." The concept of the Mystical Body became the organizing principle of the League. As Mike Lawrence said, "When you think of all men as members, actual or potential, of the Mystical Body of Christ, you begin to realize that when you persecute some of those members by refusing to let them find work or a home, you are persecuting Christ and in a sense you are persecuting yourself." ${ }^{\prime \prime 30}$

One typical evening the discussion group met for a housewarming party for Joe and Mary Jean Blough. At the time, the Catholic Messenger was serializing Mediator Dei, Pius XII's encyclical on the liturgy, and the group discussed its call for greater lay participation in the liturgy. Following the discussion, Father Ed Blough, the host's brother, and Father Cornelius Bresnahan blessed the house. Eighteen people attended the "Spiritual House-warming," and even the non-Catholic members present listened to the discussion with interest. ${ }^{31}$

president. Scott had attended summer schools of Catholic Action while still in high school. When he came to St. Ambrose he became involved with Father Kamerick and the Legion of Mary. He was among the leadership of the 1948 Catholic Action School and the Conference on Social Responsibility the next year. Upon graduation from St. Ambrose, Scott moved to Chicago, where he worked for the national office of Young Christian Students. Married in 1951, Vaile and his wife, Mary, moved back to Davenport and quickly made contact with friends in the League. The new vice-president was Rose Gravino; Shirley DeTaeye, a Marycrest graduate and YCS activist, became the secretary; and Barbara Lee was treasurer. Mike Lawrence, interview; Vaile and Mary Scott, interview with author, Oak Park, IL, 6 August 1993.

30. Catholic Messenger, 3 May 1951.

31. Catholic Messenger, 29 July 1951. Founded in 1893 by Thomas Sharon, the Messenger was a Catholic newspaper serving the state of Iowa. The paper faced financial troubles in the mid-1930s, and in 1937 the Diocese of Davenport purchased it. The bishop of Davenport became the publisher, and a succession of priests has served as the editor. Bishop Henry P. Rohlman, recognizing the 
THE MEETINGS AND DISCUSSIONS were important, but the League for Social Justice was organized to take action, so it was not long before the members entered a continuing controversy about rent controls in Davenport. During the war the government had imposed rent control as a means to avoid inflation. The controls had continued in the postwar years. In 1949 Congress extended the controls but allowed local communities to remove them by a vote of the city council and with the approval of the governor of the state. ${ }^{32}$

In the decade from 1940 to 1950 , the population of Davenport had risen by 8,150 persons, a rise of nearly 13 percent. During that same period, nearly 3,500 new housing units had been built, or one new unit for each 2.5 new persons. ${ }^{33}$ Opponents of rent control maintained that this was evidence of more than enough housing for the community and that continuing rent control would act as a disincentive for landlords to make improvements on their property. ${ }^{34}$

Bernard Buckley, a member of the Clothing Workers Union, led the proponents of continuing controls. Once the League expressed interest in rent control, Buckley joined the League and became its spokesman on the issue. Buckley and the League argued that the number of available units given by the advocates of lifting the controls did not take into account the number of housing units that had been town down. These housing

educational opportunity a diocesan newspaper afforded, declared that every Catholic home in the diocese must subscribe. Through the years the paper carried news of the Diocese of Davenport as well as national and worldwide Catholic stories. It often published the text of documents issued by the Pope and the American bishops. Moreover, various columnists wrote opinion pieces about issues of the day. Rohlman's successor as bishop (and publisher of the Messenger), Ralph L. Hayes, generally maintained a "hands-off" policy toward the paper, so the editor during the life of the League for Social Justice, Msgr. Benjamin L. Barnes, had full control of policies and personnel at the Messenger. Madeleine M. Schmidt, CHM, Seasons of Growth: History of the Diocese of Davenport, 1881-1981 (Davenport, 1981), 207-210.

32. "Rent Control - The Last Round," New Republic, 25 June 1951, 5-6; New York Times, 31 March 1949.

33. Daily Times, 21 September 1950; Iowa Official Register, 1951-52, 251.

34. See Martin Meyerson, Barbara Terrett, and William L. C. Wheaton, Housing, People, and Cities (New York, 1962), 200ff. 
units had often been occupied by poorer citizens, including many of Davenport's African Americans, who were unable to find other affordable housing. The League's chief concern was that in Davenport, as in most of the nation, the removal of rent controls would have the most devastating impact on low-income families. ${ }^{35}$ League members also pointed to evidence that the lack of adequate housing had held down Davenport's population increase. ${ }^{36}$

Over the next two years these positions defined the debate about rent control in the Davenport City Council. In May 1950 the city council had removed rent controls, but Iowa Governor William S. Beardsley had refused to approve the action. Meeting in October, the city council again visited the issue and voted six to two to remove controls. Over the next nine months, rents rose in Davenport. ${ }^{37}$

Then, in the summer of 1951, in the midst of the Korean Conflict, President Harry Truman signed a law allowing the Defense Production Authority to designate the Quad Cities as a "critical Defense housing area." League president Mike Lawrence announced that the League would wire Charles E. Wilson, director of the Office of Defense Mobilization, urging him to reimpose rent controls in Davenport. ${ }^{38}$

Members of the Chamber of Commerce housing committee met to discuss the new law. Most were opposed to the provisions that would allow rent controls. William Callihan, acting executive secretary of the Quad-City Property Owners' Association, argued that controls might be appropriate if there were a

35. Daily Times, 20 September, 5, 16, October 1950. Economist D. Gale Johnson reported that in twelve out of fourteen cities surveyed, "the largest relative rent increases [had] occurred in low-rent groups." D. Gale Johnson, "Rent Control and the Distribution of Income," American Economic Review (Papers and Proceedings) 41 (May 1951), 581.

36. An article in the Mediator, September 1951, quoted M. W. Toothman, director of the Iowa State Employment Agency, saying that the lack of adequate housing was a "handicap in recruiting skilled workment in Davenport."

37. Daily Times, 20, 21 September, 5 October 1950; Catholic Messenger, 12 July 1951. The New Republic reported that from June 1949 through February 1951 rents rose an average of 20 percent in cities with no rent control. "Rent Control - The Last Round," New Republic, 25 June 1951, 6.

38. Daily Times, 25 June 1951; Catholic Messenger, 9 August 1951. 
housing shortage. But looking through the want ads in the newspaper had convinced him that plenty of housing was available. ${ }^{39}$

The League agreed that rental units were available, but often these were not large enough or were substandard in quality or were simply too expensive. But the most serious problem was the prohibition of children in most rental properties. The League had taken a telephone survey of twenty-one landlords and found that eighteen of the twenty-one did not allow children. Pointing out that the cost of rental housing in general was high, it said that "for a man with children," housing was "difficult to obtain at any price." 40

The September issue of the Mediator listed a series of "facts" about the housing situation in Davenport and suggested a meeting of representatives from both sides of the issue. That meeting took place on September 18. William Callihan presented the familiar arguments that there were three hundred rental spaces available and that rent control would mean fewer rental properties. When asked about high rents, Callihan replied that "flyby-nighters, not [landlord] association members, charge high rents." Moreover, Callihan said, rent control was a socialist solution, and he implied that its advocates, including the League for Social Justice, were socialists if not Bolsheviks. ${ }^{41}$

Bernard Buckley spoke for the League. He disputed Callihan's assertions that rental units were available, and he pointed out that under the law, even with rent control, landlords could apply for an exemption from controls to raise rent. Dr. John

39. Daily Times, 26 June 1951; Catholic Messenger, 19 July 1951. On 6 September 1951, the Chamber of Commerce released a study claiming that there were more than three hundred unoccupied housing units in Davenport. An editorial in the Daily Times, however, said there was "considerable doubt" about that figure, adding that there was no "question about the need for expanded housing." Daily Times, 6, 8 September 1951.

40. Catholic Messenger, 16 August 1951. In its September 27 issue, the Catholic Messenger told of a man who had taken seventy calls in response to an ad for a rental apartment. Many callers asked if he took children and made promises that their children would behave. The landlord said, "To think that our country, our city, has dropped so far that renters must apologize to landlords for having a family of children."

41. Mediator, September 1951; Daily Times, 19 September 1951; Catholic Messenger, 20 September 1951. 
Martin, a Davenport optometrist, defended the League and its position on controls. At times the meeting became heated, and at the end one woman spat at the feet of Bernard Buckley as she left. ${ }^{42}$

Three days after the meeting rent controls were reimposed in Davenport. As Bernard Buckley had predicted, many landlords took advantage of the appeals provision and asked for higher rents. By the following May, national figures indicated that nearly 90 percent of such appeals had been granted, with an average rent increase of 23.5 percent. ${ }^{43}$ The rent control debate brought the League for Social Justice to public attention in Davenport. It is difficult to assess its impact on the reimposition of controls, but it is clear that segments of the business community knew that the League was challenging its activities.

FOLLOWING ITS FIGHT FOR RENT CONTROL, the League soon embarked on a project to study what member Charles Toney later called the "rigid discrimination that existed in Davenport. ${ }^{144}$ In 1950 the population of Davenport was 74,549, about 2,500 of whom were African Americans who lived primarily in two sections of the city. One area centered around Mound and Christie, above the Village of East Davenport. The other area was in central Davenport between 8th and 11th Streets and from Gaines to Harrison. ${ }^{45}$ A scattered few lived elsewhere in the city, but most were confined to the two ghettos. Most whites and many blacks were content with that arrangement.

The League for Social Justice, however, was not content. Its members suspected that not only were African Americans restricted to living in certain areas of the city, but other limits were also placed on their lives. Speaking in 1951, Charles Toney confirmed the League's suspicions. Toney noted the lack of professional services available to African Americans. Although some restaurants served blacks, he said that others did not. Factory jobs were difficult to get, and although some were

42. Daily Times, 20 September 1951; Catholic Messenger, 20 September 1951.

43. Catholic Messenger, 29 May 1952.

44. Charles Toney, interview.

45. Charles and Ann Toney, interview. 
apparently qualified, there were no African Americans in the police or fire departments. Jim Crow practices permeated the housing market, Toney said, as "real estate agents [tried] to keep the negro" in certain areas of the city. ${ }^{46}$

The League realized that change would come only when the facts were known, so that citizens could make judgments based on the facts, and action could follow. So Mike Lawrence suggested that the League study the situation to throw the "spotlight onto the Negro situation in Davenport." ${ }^{\text {"47 }}$

Under the coordination of Phyllis Miller, members gathered information in each of seven general areas: employment, housing, health, education, public places, organizations, and recreation. For example, some members called barbershops to ask whether they would accept Negro customers. Others called funeral homes, hospitals, doctors, dentists, and schools. Rose Gravino did a "spot-check" with landlords and attempted to rent an apartment. And an integrated group-Mike Lawrence, Phyllis Miller, Ted and Fannie Grant, and Manning Keigher - went to five restaurants to find out if they could get served. ${ }^{48}$

The League gathered the information and published it in November 1951 in a booklet titled Citizen 2nd Class: Negro Segregation and Discrimination in Davenport. ${ }^{49}$ It pointed out that all citizens voted, paid taxes, sent their sons to war, and obeyed the law, but because of the color of their skin, "second-class citizens" were denied the wide range of economic and social opportunities the city offered.

The report then gave details about each general area. Employment data showed that African Americans held "the worst

46. Catholic Messenger, 29 March 1951.

47. Catholic Messenger, 1 November 1951.

48. Mike Lawrence, interview; Charles Toney, interview; Ambrosian News, 9 November 1951; Catholic Messenger, 4 October, 1 November 1951; Mediator, September 1951.

49. Catholic Messenger, 1 November 1951. The text was written by Jerome Cahill. A recent graduate of Marquette University, Cahill had come to Davenport to work at the Catholic Messenger. Tom Chouteau, a 1951 St. Ambrose graduate, did the cover art and illustrations. Catholic Messenger, 21 June 1952; Jerome Cahill to author, 30 August 1993. A copy of the booklet is in the author's possession. 


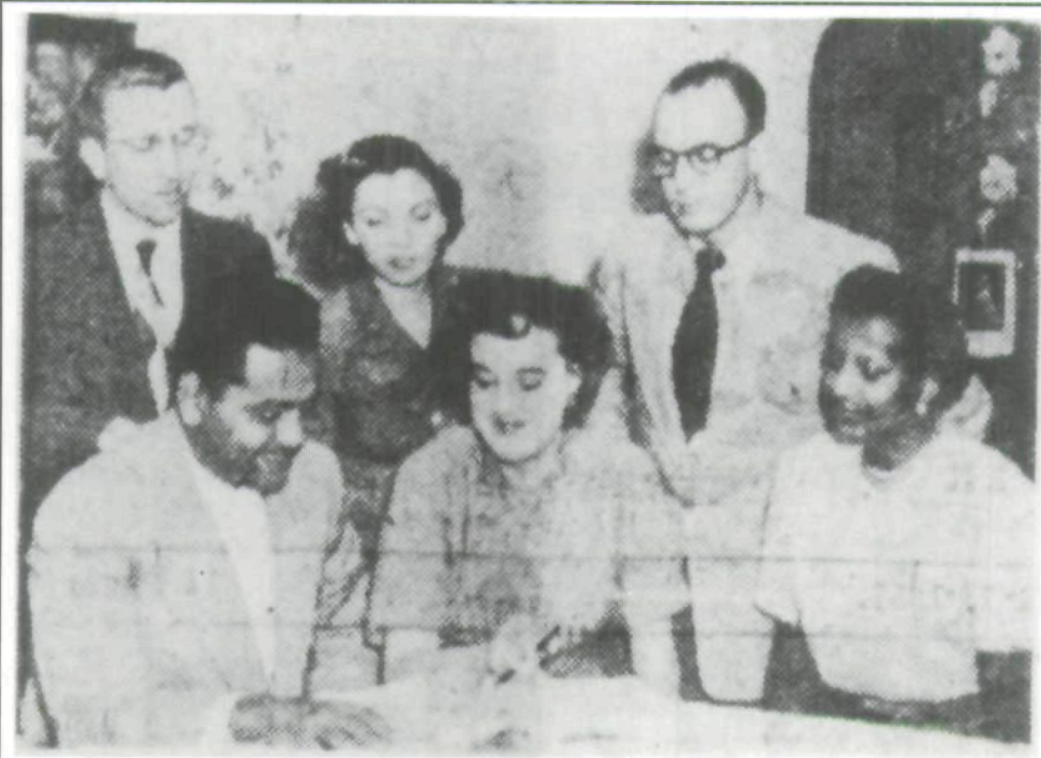

Members of the League for Social Justice involved in planning for the distribution of Citizen 2nd Class included (front row, left to right) Charles Toney, League vice-president; Phyllis Miller, chair of the League's discrimination survey project; Fannie Grant; (back row) James Lawrence; Rose Gravino; and Franz Klouda. Photo from the Catholic Messenger, November 1, 1951.

jobs - as sweepers, janitors and manual laborers - regardless of skill or merit." There were no teachers, office workers, firemen, or policemen from the black community. A survey showed that in eighteen large firms, with a total of more than ten thousand workers, only 175 workers were black. Some personnel managers said they would hire blacks but that few had the necessary job skills. ${ }^{50}$

In health care, 14 of 79 doctors said they would not treat African Americans at all; others said they would treat them but only during off-duty hours. Only a "handful" would treat them "without qualification." Over half of the dentists ques-

50. Citizen 2nd Class: Negro Segregation and Discrimination in Davenport (Davenport, 1951), 3. 
tioned said they would not accept black patients. Mercy and St. Luke's hospitals admitted black patients and permitted black doctors to practice in the hospital. Osteopathic hospital, however, neither admitted black patients nor had blacks among its doctors and nurses. A spokesman said the hospital had "no facilities for them. ${ }^{\prime 51}$

In education the record was somewhat better. Only Palmer College of Chiropractic and a local business school refused to admit African Americans. Public places, recreation facilities, and organizations that were tax supported generally did not practice discrimination. But privately owned facilities, such as restaurants and hotels, either "discouraged" blacks from entering or blatantly prohibited them. Of the five cemeteries in Davenport, two refused to bury blacks, one would bury them in a segregated section, and the other two had no restrictions. ${ }^{52}$

The integrated group that surveyed five restaurants found that three offered integrated service. The manager of another restaurant said that he was not personally prejudiced but that all the tables were previously reserved and he offered service in an upstairs room. In the fifth establishment the waitresses first ignored the group and then said they were "too busy" to wait on them. Writing about their experience in the Mediator, Mike Lawrence said that the most common objection businessmen made to serving blacks was that they would lose white customers. However, establishments that did serve blacks did not experience a loss in business, thus highlighting the irrationality of racial discrimination. ${ }^{53}$

In a concluding note to "Mr. and Mrs. Davenport," the League said that discrimination existed because of ignorance and fear that if a white businessman tried to serve Negroes he would lose his white customers, or his white employees would object. It urged white Davenport to open its mind, study the facts, and then summon the courage to change. ${ }^{54}$

51. Ibid., 7-8.

52. Ibid., 10-11.

53. Ibid.; Catholic Messenger, 4 October 1951; Mediator, September 1951.

54. Citizen 2nd Class, 14-15. 
The League sent five hundred copies of the pamphlet to schools, libraries, prominent citizens, social agencies, and employers throughout the city as well as to local and state newspapers. ${ }^{55}$ The editor of the Davenport Daily Times said that the League had "held up a mirror to Davenport's treatment" of its Negro citizens. Praising the "calm and matter-of-fact tone" of the study, he said that it was "wise from time to time to have our shortcomings revealed." He concluded that there was "no more worthy object" than the League's goal of fair treatment for all. The editor of Davenport's other daily newspaper, the Morning Democrat, also praised the work of the League. He hoped that similar surveys would be done "from time to time." The "veil has been ripped off the whole subject," he acknowledged, adding that the "barriers created by ignorance must be knocked down one by one." Both editors noted that Davenport's record was not as good as the cities on the Illinois side of the river. But, the Democrat said, now that the League for Social Justice had "charted the 'bad spots,'" the citizens of Davenport "should band together in an effort to pull remaining prejudices out by the roots." ${ }^{\prime 56}$

Citizen 2nd Class received some notice elsewhere in the state and nation. The Des Moines Register carried a story about it, and Interracial Review, published by the New York Catholic Inter-racial Council, reprinted a Catholic Messenger story about the survey. ${ }^{57}$ But for the most part it was put aside. It did, however, crystallize the issue of racism and discrimination in Davenport, and it provided a marker by which to measure progress over the succeeding years.

WITHIN WEEKS of the publication of Citizen 2nd Class, the League took on discrimination against a settlement of MexicanAmericans who lived at Cook's Point in Davenport. Named for Ebenezer Cook, a pioneer lumberman and civic leader, the Point

55. Barbara Lee Papers, in author's possession. News stories about Citizen Second Class appeared in the Davenport Daily Times, 1 November 1951; the Rock Island Argus, 1 November 1951; and the Moline Daily Dispatch, 1 November 1951.

56. Daily Times, 2 November 1951; Morning Democrat, 3 November 1951.

57. Des Moines Register, 2 November 1951; "The Racial Survey - A Davenport Commentary," Interracial Review: A Journal for Christian Democracy, February 1952, 24-25. 
was located at the end of Howell Street, between the railroad tracks, the entrance to Credit Island, and the river. One resident remembered that during the years they lived there the city began to use the adjacent area for the city dump. The city, he claimed, did not worry "who lived there or anything" and did not ask anybody about the dump. ${ }^{58}$

Mexicans had first immigrated to the Quad City area during World War I to work at the Bettendorf Foundry. At first they lived close to the plant in Bettendorf in a settlement called the "Holy City." But during the 1920s they began to form a squatter settlement on Cook's Point. By the early 1940s all of the residents of the "Holy City" had moved to Cook's Point. ${ }^{59}$ The area that developed had one U-shaped, unpaved street, no running water, one pump that served all the residents, and no sanitation facilities. Many houses were little more than shacks or even packing cases, although in time some more substantial residences were built. Some houses were raised on stilts to provide protection from spring flooding. In 1942 Albert Uchtorff, a local industrialist and developer, bought the land and began to charge the residents two dollars per month for rent. ${ }^{60}$

In 1949 the Industrial and Human Relations Club at St. Ambrose, another of Father Bill O'Connor's organizations, had done an extensive survey of the Point. The survey found that 270 people, most of whom were Mexican-Americans, lived in 56 homes on the Point, often in very crowded conditions. One family of thirteen lived in three rooms, another family of thirteen in four rooms, and eight homes had two families each. Sixty-eight people were employed full time. One adult had a high school degree, but most had not gone beyond eighth grade.

58. Jim Arpy, "Remembering Cook's Point," Times Democrat, 22 August 1974; Marcellino Herrera, interview with author, Davenport, 3 August 1993. See also Rev. William T. O'Connor, "Racial Injustice in Iowa," Labor 26 (October, November 1963); Grace Nuñez, "Voices of a Different Color: An Oral History of Eastern Iowa Mexican American Women" (M.A. project, University of Iowa, 1993). On August 3, 1993, I interviewed a group of former residents of Cook's Point: Salvador Lopez, Ray Martinez, Mary Terronez, Nick Juarez, Marcellino Herrera, Frank Ramirez, and Henry Vargas. Their collective memory provided essential background for this section of the article.

59. Ambrosian News, 29 April 1949.

60. Ibid.; O'Connor, "Racial Injustice." 
Most of the children were in school, some at St. Alphonsus grade school, the rest in public school. For recreation the children played either in the mud street or in the nearby city dump. The lack of sanitation and the proximity to the dump resulted in a high incidence of disease, including tuberculosis. ${ }^{61}$

Mexican-Americans had not been included in the statistics in Citizen 2nd Class, but many of the same conclusions would also apply to them. As the O'Connor survey showed, they did have jobs but usually the dirtiest factory jobs. Some doctors would not treat them, nor would some barbers cut their hair. Whites would not take an empty seat beside them on city buses or, if a Mexican-American took a seat, would stand rather than sit beside them. Once when one resident entered a bar, the bartender served him a beer but pointedly broke the mug rather than use it again.

On May 4, 1949, the St. Ambrose students appeared before the Davenport City Council to present the results of their survey and to request recreation facilities for children on the Point. The students met a "chilly" reception. Alderman John Fell, who represented the ward that included Cook's Point, said that "a playground would encourage those people to remain in that location," and that he was in favor of moving them off the land so that the owner could develop the area. Fell said the St. Ambrose students would do a "public service" if they found other homes for the residents. ${ }^{62}$

In the next three years some families moved from the Point, but the situation remained essentially unchanged until January 1952, when Mr. Uchtorff notified the residents that they must move by June 1 because A. Linton Lundy, president of Midwest Metals, hoped to build a factory on the site. Aware that this would create a problem for the residents, Uchtorff told the city council that, nevertheless, such a move would create better conditions for the people. "Certainly the children should be provided with better housing facilities" than their current ones, he

61. Ambrosian News, 25 March, 22 April 1949; "Cook's Point Economic Survey: Tabulation of Results," O'Connor Papers; Daily Times, 22 April 1949; Democrat and Leader, 22 April 1949.

62. Daily Times, 5 May 1949; Democrat and Leader, 5 May 1949. 
said, which have no street lights or sanitary facilities. The residents were skeptical of this explanation. As one later commented, "talk is cheap." 63

On February 25 League members Jerome Cahill and Ann Toney surveyed the Point. Walking through "ankle-deep mud," they talked with the twenty-seven families who still lived there. Twenty-one of those families said they neither owned nor could afford to buy property. What they needed was low-cost rental property. Writing in the Catholic Messenger, Cahill said the question most often asked by the residents was "where are we going to go?" ${ }^{\prime 64}$

Nonetheless, Mr. Lundy announced that he would go ahead with plans to clear the area. In another Messenger article, Cahill said this announcement increased the pressure on the residents; what was needed was an "all-out effort by the people of Davenport and their civic leaders to relocate the white and Mexicanorigin Cook's Point dwellers." But, Cahill concluded, such an effort, "until now," had not been forthcoming. ${ }^{65}$

In the meantime, Ann Toney and Cahill had presented the results of the League's survey to the Davenport City Council and the Chamber of Commerce. They had also contacted a local realtor, Paul Ryan, to determine the availability of housing. Although he was not optimistic that housing could be found, Ryan acknowledged that the issue was clear: the "eviction proceedings" presented a "definite problem and obligation" for the city of Davenport. As a consequence of the League's actions, a Citizens' Committee was formed in early March. Chaired by Paul Ryan, the committee included prominent bankers, real estate agents, clergymen, businessmen, and two aldermen.

63. Daily Times, 6 February 1952; Frank Ramirez, interview with author, Davenport, 3 August 1993.

64. Catholic Messenger, 28 February 1952.

65. Catholic Messenger, 6 March 1952. Cahill's strongly worded articles cost him his job at the Messenger. Mr. Lundy complained to Msgr. Thomas J. Feeney, chancellor of the Diocese of Davenport, about Cahill. The Messenger published an unsigned letter from Feeney claiming that Cahill had portrayed Lundy as an "industrial octopus strangling the down-trodden." Upon receipt of the letter, the editor of the paper, Father Benjamin Barnes, asked Cahill if he was "happy" at the paper. Cahill left the Messenger shortly thereafter. Catholic Messenger, 13 March, 12 June 1952; Cahill to author, 30 August, 10 September 1993. 
Ryan's first action as chair was to ask the League for Social Justice to do yet another survey of the needs of the Cook's Point community. Ryan hoped that the survey would show what "can be done and what might be done" about the situation. "We're certainly looking for an answer," he said. ${ }^{66}$

On March 13 a dinner meeting of about 150 people included the Citizens' Committee, Cook's Point residents, League members, and other interested parties. To emphasize the family nature of the problem, many of the Mexican-American families brought their children and infants. As the meeting began, the League reported the results of their latest survey, which found that twenty-three families (comprising 133 people of Mexican origin and twenty others) still lived on the Point. Of these, nineteen families (124 persons) had "critical" housing needs. Manual J. Juarez, a spokesman for the families, said they did not want "relief," just the opportunity to find affordable housing. ${ }^{67}$

The ensuing discussion brought out two aspects of the housing problem. First was the availability of housing. The League's survey the previous summer during the rent control battle had shown that housing was not available for people with children. That situation had not changed; according to Paul Ryan, there was simply no rental housing available for anybody, "regardless of race, creed or color." ${ }^{\prime \prime 8}$

Dr. John Martin, a member of the Citizens' Committee, raised the second aspect of the housing problem. Martin wondered if the central question was that the Cook's Point residents were of Mexican origin and therefore not "acceptable as neighbors" in other parts of Davenport. For example, someone suggested that a tract of land be found so all of the Cook's Point residents could move together. Donald McDonald, a reporter for the Catholic Messenger and a member of the Citizens' Committee, agreed; he said it would probably be easiest to keep the residents together. But former Davenport mayor Ed Frick, also

66. Charles and Ann Toney, interview; Moline Daily Dispatch, 18, 28 March 1952; Ambrosian News, 2 May 1952.

67. O'Connor, "Racial Injustice"; Daily Times, 14 March 1952; Morning Democrat, 14 March 1952.

68. Morning Democrat, 14 March 1952. 
a member of the Citizens' Committee, said it would be a "big mistake" to create another Cook's Point. Rabbi Abram Goodman also spoke against any attempt to segregate the MexicanAmericans, declaring that "Mexicans are not segregated in the United States army or navy, nor is a dead veteran denied decent burial in Davenport. But live veterans and their families are being denied decent housing. ${ }^{\prime 69}$

The emotional high point of the meeting came when Mrs. Mary Terronez rose to speak. Often speaking through tears, she told of growing up on the Point and of playing at the city dump, where she had to conquer her fear of the huge water rats. At a certain age she came to realize that her life was different from the lives of her classmates in school. She had become ashamed of where she lived and would even refuse to cross the tracks to return home until her mother would come to get her for supper. Her anger rising, she denied the assertions some had made that the Mexicans liked to live in the squalor of Cook's Point. "We don't like to live in an area like Cook's Point any more than you people would like to live there. And we want our children to grow up in as good an environment as your children." "I was mad," she recalled years later. ${ }^{70}$

It seems clear that the Citizens' Committee had mixed motives. Some, like Ryan, genuinely wanted to find homes for the residents. Others wanted to find them homes, but keep them segregated from the rest of the community. Nevertheless, as the meeting ended everyone agreed that housing must be found.$^{71}$

A few days later developer Kenneth Fell proposed to build housing on lots he owned in the Nahant Marsh area of extreme southwest Davenport- "down in the sticks," as the residents recalled. The area was low and marshy and subject to frequent flooding. But the attitude seemed to be that the Cook's Point residents were "used to" living by the river, so this would not be a hardship. Fell hoped to spend sixty thousand dollars to

69. Morning Democrat, 14 March 1952; Moline Daily Dispatch, 14 March 1952.

70. Catholic Messenger, 20 March 1952; Mary Terronez, interview with author, Davenport, 3 August 1993; O'Connor, "Racial Injustice.

71. Daily Times, 19, 20, 22 March 1952; Morning Democrat, 20, 22 March 1952; Catholic Messenger, 27 March 1952. 
build as many houses as needed for the Cook's Point residents. Alderman Ray O'Brien, who thought this would be the "finest possible solution," hoped that no one would object to Fell's proposal. He added, however, that to avoid another Cook's Point, "we should insist that [the] homes be properly maintained."72

An editorial in the Davenport Morning Democrat agreed that since no rental housing was available, Fell's proposal seemed to be the "only possible answer." Besides, the editorial continued, the residents were united by cultural and family ties, so they would probably be happier together. This would not be "segregation," it said, but rather doing the best possible thing for the moment. ${ }^{73}$

One obstacle to Fell's plan was the fear that the proposed houses would not meet current building codes. But the superintendent of public works, Ralph Graham, examined the plans and said they would meet specifications. ${ }^{74}$ Another, more serious problem concerned zoning. The area was zoned for heavy commercial use. For Fell's plan to work, it would have to be rezoned. When the plan was presented to the city council on March 21, owners of adjacent property appeared to oppose rezoning. They were afraid that allowing residential units to be built in the area would make adjacent property less desirable for the industrial development they had planned. Their objections carried the day. The housing project was doomed. Speaking following the meeting, Paul Ryan said that industry was "kicking these families off Cook's Point, and now here is industry keeping them from moving to another place. ${ }^{\prime 75}$

In the meantime, the same weekend as the failure of the Fell plan, the Citizens' Committee and League members did another survey to ascertain the financial resources of the residents of Cook's Point. Twenty-three families remained on the Point. Six families had secured property on which they hoped

72. Mary Terronez and other former residents of Cook's Point, interview; Daily Times, 19 March 1952; Moline Daily Dispatch, 19 March 1952; Morning Democrat, 19, 22 March 1952.

73. Morning Democrat, 22 March 1952.

74. Daily Times, 20 March 1952; Morning Democrat, 20 March 1952.

75. Morning Democrat, 22 March 1952; Catholic Messenger, 27 March 1952. 
to build, but the other seventeen families still needed help. The families had weekly incomes ranging from 35 to 136 dollars. Nearly all were in debt. Some had life insurance, and at least six were eligible for GI loans. About half of the families said they could make down payments on property. The problem remained for them to find property ${ }^{76}$

As he had predicted, Paul Ryan had been unable to find rental housing. Twice he asked the Property Owners Association for a list of available housing; both times he was told that nothing was available. The April 10 issue of the Mediator reported that he had located seven houses for purchase, ranging from $\$ 2,500$ to $\$ 7,500$, but that fifteen families still had nowhere to go. ${ }^{77}$ Even those who could afford to buy found their offers rejected when neighbors put pressure on realtors. Salvador Lopez recalled that his father had put a down payment on a house at Eighth and Tremont, but when he appeared at the closing the deal fell through. ${ }^{78}$

The most publicity came, however, when D. S. Olvera, his brother, Ramon, and their sister, Clara, purchased a new home in Moline from Davenport contractor Richard Collignon. When the Olveras' prospective neighbors found out, they pressured Collignon not to sell to the Olveras. Collignon wrote an apologetic letter to the Olveras, stating that if they would return the contract, he would return their down payment plus fifty dollars. Nevertheless, Collignon said they were "good citizens and good neighbors" who were entitled to live where they wanted. The Olvera story continued in the newspapers for several days before the opposition disappeared and the Olveras finally moved into their new home. ${ }^{79}$

The head of another family, Dionisio Ramirez, found six acres of property with a house on it on old Highway 22 west

76. Morning Democrat, 22 March 1952; Catholic Messenger, 27 March 1952.

77. Catholic Messenger, 10 April, 29 May 1952; Mediator, 10 April 1952.

78. Ray Martinez, interview with author, Davenport, 3 August 1993; Salvador Lopez, interview with author, Davenport, 3 August 1993. For other examples of such discrimination, see O'Connor, "Racial Injustice."

79. Daily Times, 18, 19, 20, 21 March 1952; Morning Democrat, 18, 19, 21 March 1952; Daily Dispatch, 18, 19, 21 March 1952. 
of Davenport, where he hoped to move, along with his two married daughters and two married sons and their families. Ramirez had first attempted to purchase property at Fifth and Warren Streets, but when the payments were increased beyond his ability to pay, he was forced to withdraw his offer. With the Highway 22 property, neighbors objected and circulated petitions to prevent the Ramirez family from occupying the land. Ramirez was more concerned, however, about whether the houses would be ready by the June 1 deadline. First, they had to build a road into the area; then they had to dig basements and septic systems. League members agreed to help, and Charles Toney went to Bishop Hayes to ask if St. Ambrose seminarians could be enlisted as well. On an April Saturday, twenty-four St. Ambrose students were trucked out to the site

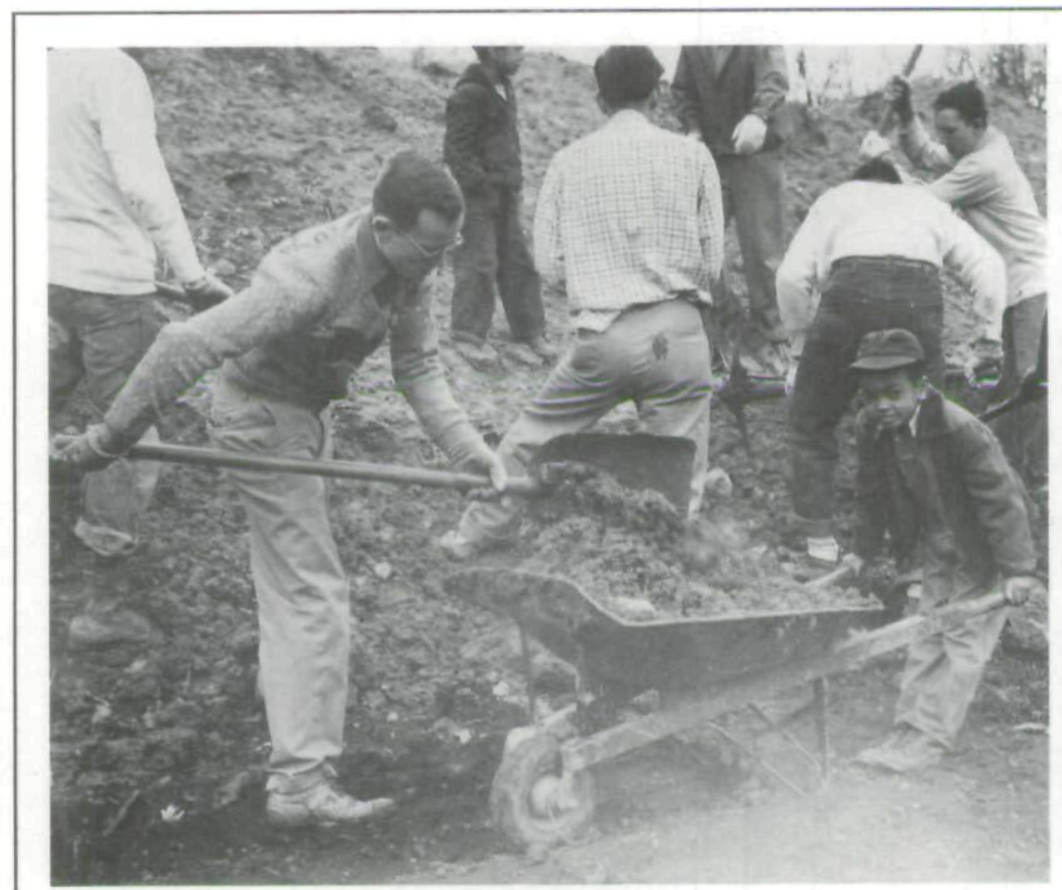

St. Ambrose College students work with other volunteers to prepare the site for homes for Mexican-American families forced out of Cook's Point. Photo from Davenport Democrat and Times, April 6, 1952. 

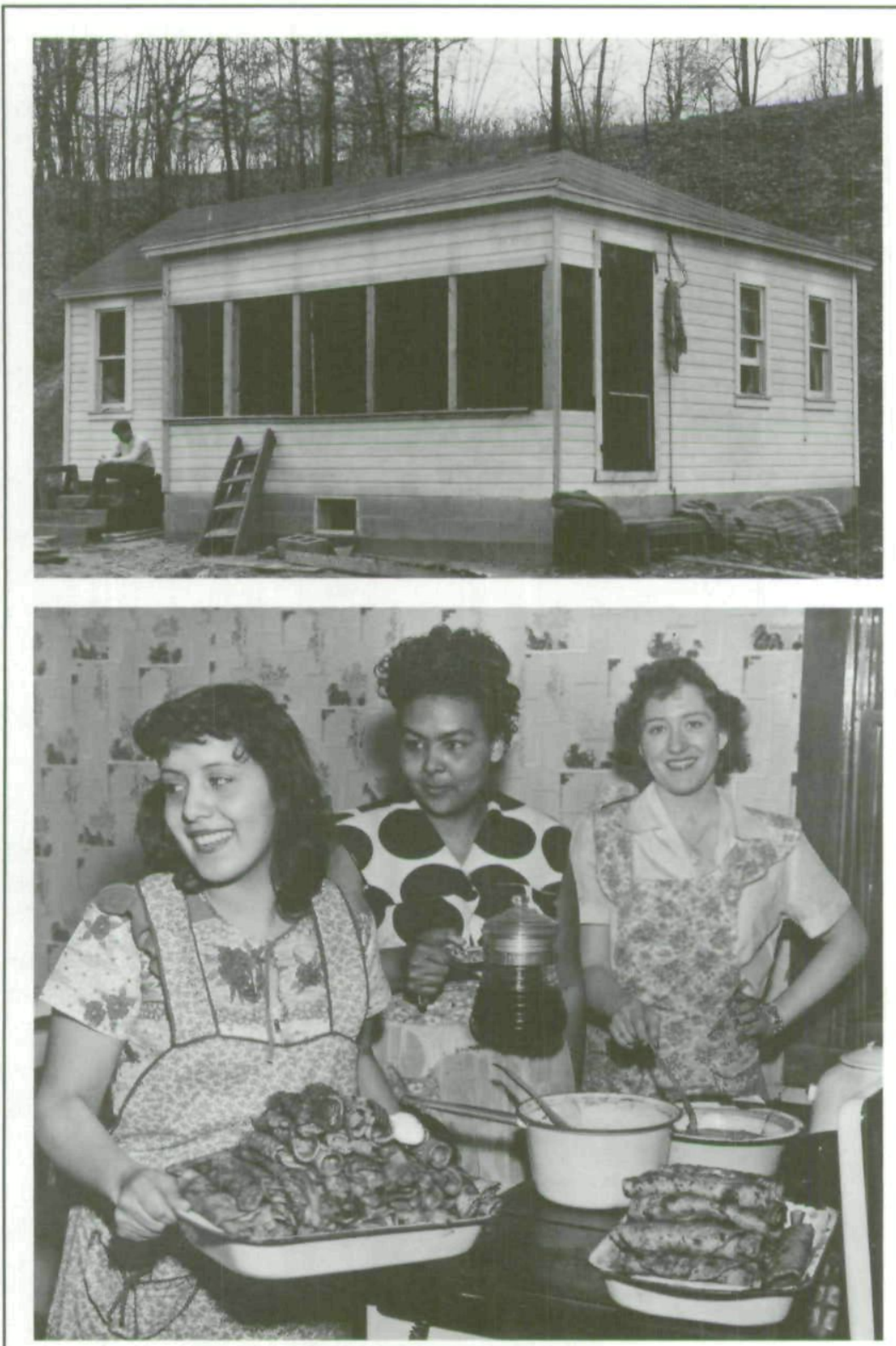

Top: The first of the homes built for Mexican-American families forced out of Cook's point stands nearly completed.

Bottom: Three volunteers prepare enchiladas for laborers working on the homes. Photo from Davenport Democrat and Times, April 6, 1952. 
for a full day's work. A St. Ambrose graduate, Peter Bushma, a concrete contractor, taught them how to mix mortar and lay bricks. Over the next few weeks three houses were moved in, and one was built on the site. With the help of this large work force, the Ramirez families were able to move in on time. ${ }^{80}$

The last of the residents left Cook's Point in August. All had found housing - some on their own initiative, others with the involvement of Paul Ryan of the Citizens' Committee and members of the League. For members of the League for Social Justice, the Cook's Point experience was Catholic Action in action. It gave them the opportunity to apply the Jocist principles of see, judge, act in a "real world" situation.

\section{IT HAD BEEN A HEADY YEAR-AND-A-HALF since the} League had been formed. With the fight for rent control, the publication of Citizen 2nd Class, and their involvement in Cook's Point, the members had been engaged in almost nonstop activity. Now some members, including Charles and Ann Toney, Vaile and Mary Scott, and some members of the Cook's Point community, considered obtaining some rural land to form an interracial community. The proposed community illustrated the idealism that had motivated the League. But such a venture would take money, and they were never able to put enough together to make their dream a reality.

The League continued for another year or so. Many members had growing families, which put other demands on their time. Others, including the Scotts, the Lawrences, and Jerome Cahill, had moved away. In its brief existence, the League for Social Justice had challenged the status quo in an era when the prevailing ideology was conformity. But the issues raised by the League in the early 1950s - discrimination, opportunity, and social justice - would reappear a decade later, and many League members would continue the fight. A few years later,

80. Perry Ramirez, interview with author, Davenport, 6 January 1995; Mary Terronez and Frank Ramirez, interview with author, Davenport, 3 August 1993; Charles and Ann Toney, interview; Rev. Marvin Mottet, interview; Vaile and Mary Scott, interview; Sunday Democrat and Times, 6 April 1952; Catholic Messenger, 10 April 1952. 
when the Catholic Interracial Council was formed in Davenport, many former Leaguers joined in the new battles.

It is difficult to measure precisely the impact the League had on the issues it addressed. It had joined the rent control fight that was already in progress. Citizen 2 nd Class attracted a small amount of attention at the time and then gathered dust. The League's actions did make a difference for the MexicanAmericans of Cook's Point. Not only did League activity serve as a catalyst for the formation of the Citizens' Committee, but League members and St. Ambrose students provided physical assistance to help the families move.

But the League's larger impact was on the members themselves. Their consciousness was raised about the issues of race and discrimination. Writing years later, Bill Nagle said that his time at St. Ambrose and with the League "created in [him] a social conscience and an activism for social justice." Mary Jean Blough spoke of her "personal awakening" about the issue of race and said that she and her husband, Joe, remained active in civil rights issues throughout the 1960s. Mike Lawrence, who has remained active in labor and civil rights issues, says of the League, "what we really did change was ourselves." ${ }^{81}$

The League for Social Justice existed in the decade that has been called the "heyday" of Catholic Action. In the next decade the Catholic Church renewed itself through the deliberations of the Second Vatican Council, which called the laity to take a greater leadership role in the church. As historian Jay P. Dolan notes, Catholic Action groups (such as the League for Social Justice) served as "good training ground for such leadership." ${ }^{12}$

The study of the social encyclicals by League members, their discussions of the place of the liturgy and worship in their lives, their exposure to the Jocist methodology, and the example of the Chicago groups all contributed to the decision to form a

81. Mike Lawrence to author, 22 December 1993; Bill Nagle to author, 7 October 1993; Joe and Mary Jean Blough, interview. Writing of Young Christian Workers active in Chicago at the same time, Mary Irene Zotti says, "they did not change the world ... [but] they were changed. Zotti, A Time of Awakening, 306.

82. Campbell, "Heyday of Catholic Action," 222; Dolan, American Catholic Experience, 396. 
group to put their ideals into action. But the key to the activism of League members was the education they received at St. Ambrose College or their contact with members of the faculty there. It was an education that combined the theoretical with the practical. This had changed them, and they hoped to change society. Mike Lawrence remembered that his work for justice with the League was "a sensational experience," adding, "we thought we were going to make a difference. ${ }^{1{ }^{\prime \prime} 3}$

83. Mike Lawrence, interview. 
Copyright of Annals of Iowa is the property of State of Iowa, by \& through the State Historical Society of Iowa and its content may not be copied or emailed to multiple sites or posted to a listserv without the copyright holder's express written permission. However, users may print, download, or email articles for individual use. 